Keywords: $M C U, A R P, I S D P$

Retention: Permanent

\title{
Results of Initial Analyses of the Macrobatch 5 Tank 21H Qualification Samples
}

T. B. Peters

S. D. Fink

January 2012

Savannah River National Laboratory Savannah River Nuclear Solutions

Aiken, SC 29808

Prepared for the U.S. Department of Energy under

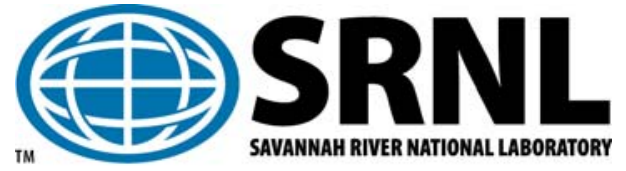
contract number DE-AC09-08SR22470. 
SRNL-STI-2012-00025

Revision 0

\section{DISCLAIMER}

This work was prepared under an agreement with and funded by the U.S. Government. Neither the U.S. Government or its employees, nor any of its contractors, subcontractors or their employees, makes any express or implied:

1. warranty or assumes any legal liability for the accuracy, completeness, or for the use or results of such use of any information, product, or process disclosed; or

2. representation that such use or results of such use would not infringe privately owned rights; or

3. endorsement or recommendation of any specifically identified commercial product, process, or service.

Any views and opinions of authors expressed in this work do not necessarily state or reflect those of the United States Government, or its contractors, or subcontractors.

Printed in the United States of America

Prepared for

U.S. Department of Energy 


\section{REVIEWS AND APPROVALS}

\section{AUTHORS:}

T. B. Peters, Author, SRNL/SASP

Date

TECHNICAL REVIEW:

C. A. Nash, Technical Reviewer, SRNL/ACP

Date

APPROVAL:

S. D. Fink, SRNL/SASP, Manager

Date

S. L. Marra, SRNL/E\&CPT Research Programs, Manager

Date

D. J. Martin, Manager, H Tank Farm Engineering

Date 


\section{EXECUTIVE SUMMARY}

Savannah River National Laboratory (SRNL) analyzed samples from Tank 21H in support of qualification of Salt (Macro)Batch 5 for the Integrated Salt Disposition Project (ISDP). This document reports the initial results of the analyses of samples of Tank $21 \mathrm{H}$. No issues with the projected Salt Batch 5 strategy are identified. 


\title{
LIST OF ABBREVIATIONS
}

\author{
AD - Analytical Development \\ ICPES - inductively-coupled plasma emission spectroscopy \\ RSD - relative standard deviation \\ SRNL - Savannah River National Laboratory \\ TIC/TOC - Total Inorganic Carbon/Total Organic Carbon \\ TTR - task technical request \\ TTQAP - task technical and quality assurance plan
}




\subsection{Introduction}

This report describes the laboratory results of Salt (Macro)Batch 5 preliminary samples from Tank 21H. These results will be used by Tank Farm Engineering for their blend calculations. This work was specified by Technical Task Request (TTR) ${ }^{1}$ and by Task Technical and Quality Assurance Plan (TTQAP). ${ }^{2}$

Details for the work are contained in controlled laboratory notebooks. ${ }^{3}$

\subsection{Experimental Procedure}

Five Tank 21H samples (i.e., dip sample bottles HTF-21-11-114, HTF-21-11-115, HTF21-11-116, HTF-21-11-117, and HTF-21-11-118) arrived at SRNL on October 13, 2011. The samples were optically clear, with no visible solids present. Researchers measured the density of each of the solutions. With customer concurrence, the samples were combined and mixed. After combining, duplicate filtered samples (using a $0.45 \mu \mathrm{m}$ syringe filter) were sent to Analytical Development (AD) for analysis. Samples were not diluted before delivery to AD.

\subsection{Results and Discussion}

The results of the density measurements are listed in Table 1.

Table 1. Sample Density Measurements $\left(25^{\circ} \mathrm{C}\right)$

\begin{tabular}{|c|c|}
\hline Sample & Measured Density (g/mL) \\
\hline HTF-21-11-114 & 1.306 \\
\hline HTF-21-11-115 & 1.315 \\
\hline HTF-21-11-116 & 1.292 \\
\hline HTF-21-11-117 & 1.292 \\
\hline HTF-21-11-118 & 1.301 \\
\hline Average (\%RSD) & $1.301(0.75 \%)$ \\
\hline
\end{tabular}

The analytical uncertainty is typically $<1 \%$ for density measurements.

The results of the ICPES analysis are listed in Table 2. 
Table 2. ICPES Results

\begin{tabular}{|c|c|c|c|}
\hline Analyte & Result (mg/L) & Analyte & Result (mg/L) \\
\hline $\mathrm{Ag}$ & $<1.46$ & $\mathrm{Mo}$ & $7.79(8.45 \%)$ \\
\hline $\mathrm{Al}$ & $7125(0.10 \%)$ & $\mathrm{Na}$ & $146000(0.49 \%)$ \\
\hline $\mathrm{B}$ & $35.8(0.40 \%)$ & $\mathrm{Ni}$ & $<1.6$ \\
\hline $\mathrm{Ba}$ & $<0.52$ & $\mathrm{P}$ & $168(0.84 \%)$ \\
\hline $\mathrm{Be}$ & $<0.08$ & $\mathrm{~Pb}$ & $<7.16$ \\
\hline $\mathrm{Ca}$ & $<0.56$ & $\mathrm{~S}$ & $2940(0.00 \%)$ \\
\hline $\mathrm{Cd}$ & $0.850(1.66 \%)$ & $\mathrm{Sb}$ & $<10.7$ \\
\hline $\mathrm{Ce}$ & $<6.03$ & $\mathrm{Si}$ & $46.8(1.66 \%)$ \\
\hline $\mathrm{Cr}$ & $41.0(0.34 \%)$ & $\mathrm{Sn}$ & $<5.61$ \\
\hline $\mathrm{Cu}$ & $1.29(23.7 \%)$ & $\mathrm{Sr}$ & $<0.05$ \\
\hline $\mathrm{Fe}$ & $5.54(0.64 \%)$ & $\mathrm{Th}$ & $<2.68$ \\
\hline $\mathrm{Gd}$ & $<2.15$ & $\mathrm{Ti}$ & $<0.38$ \\
\hline $\mathrm{K}$ & $324(2.40 \%)$ & $\mathrm{U}$ & $<32.7$ \\
\hline $\mathrm{La}$ & $<0.67$ & $\mathrm{~V}$ & $<0.47$ \\
\hline $\mathrm{Li}$ & $10.4(0.68 \%)$ & $\mathrm{Zn}$ & $4.40(0.64 \%)$ \\
\hline $\mathrm{Mg}$ & $<0.15$ & $\mathrm{Zr}$ & $>0.25$ \\
\hline $\mathrm{Mn}$ & $<0.53$ & & \\
\hline
\end{tabular}

ICPES analytical uncertainty is $10 \%$. The values in the parentheses are the percentage residual standard deviation (RSD).

Results from the IC Anions, Free Hydroxide, and TIC/TOC are listed in Table 3.

Table 3. IC Anions, Free Hydroxide and TIC/TOC Results

\begin{tabular}{|c|c|}
\hline Analyte & Result (mg/L) \\
\hline IC Anions & \\
\hline $\mathrm{F}^{-}$ & $<10$ \\
\hline $\mathrm{Cl}^{-}$ & $<500$ \\
\hline $\mathrm{Br}^{-}$ & $<500$ \\
\hline Formate & $<10$ \\
\hline Nitrite & $25750(5.77 \%)$ \\
\hline Nitrate & $175000(5.27 \%)$ \\
\hline Phosphate & $485(13.7 \%)$ \\
\hline Sulfate & $7305(4.36 \%)$ \\
\hline Oxalate & $242(20.5 \%)$ \\
\hline TIC & $2860(2.97 \%)$ \\
\hline TOC & $220(5.14 \%)$ \\
\hline Free Hydroxide & $2.08 \mathrm{M}(2.04 \%)$ \\
\hline
\end{tabular}


The analytical uncertainty for the IC results is $10 \%$. The analytical uncertainty for the TIC/TOC results is $10 \%$. The analytical uncertainty for the Free Hydroxide result is $10 \%$. The values in the parentheses are the \%residual standard deviation (RSD).

The TIC and TOC results are in terms of $\mathrm{mg} / \mathrm{L}$ of carbon. If we assume that the entire TIC result is carbonate, this translates to a carbonate concentration of $0.238 \mathrm{M}$.

Results from the gammascan $\left({ }^{137} \mathrm{Cs}\right)$ are listed in Table 4.

Table 4. ${ }^{137}$ Cs Results

\begin{tabular}{|c|c|c|}
\hline Analyte & Result (pCi/mL) & Result (Ci/gal) \\
\hline${ }^{137} \mathrm{Cs}$ & $5.90 \mathrm{E}+07(0.00 \%)$ & 0.223 \\
\hline
\end{tabular}

The analytical uncertainty of the ${ }^{137}$ Cs measurement is $5.00 \%$. The values in the parentheses are the percentage relative standard deviation (RSD).

\subsection{Conclusions}

Analysis of the Tank $21 \mathrm{H}$ sample indicates that the material does not display any unusual characteristics. Further sample results will be reported in a future document. 


\subsection{References}

${ }^{1}$ A. R. Shafer, “Qualification of ISDP Salt Batch 5”, HLW-DWPF-TTR-2012-0001, October 17, 2011.

${ }^{2}$ T. B. Peters and S. D. Fink, "Task Technical and Quality Assurance Plan for ISDP Salt Batch 5 Sample Qualification”, SRNL-RP-2011-01629, Rev.0, November 16, 2011.

${ }^{3}$ T. B. Peters, “ISDP5”, SRNL-NB-2012-00017, January 30, 2012. 


\section{Distribution:}

E. J. Freed, 704-56H

D. J. Martin, 241-152H

M. W. Geeting, 241-152H

B. A. Gifford, 704-56H

S. P. McLeskey, 241-152H

K. L. Lang, 704-27S

B. A. Oard, 241-197H

R. E. Edwards, Jr., 773-67A

K. D. Harp, 766-H

S. G. Campbell, 992-5W

S. L. Marra, 773-A

A. B. Barnes, 773-A

C. C. Herman, 99-W

B. J. Giddings, 786-5A

F. M. Pennebaker, 773-42A

S. D. Fink, 773-A

T. B. Peters, 773-42A

C. A. Nash, 773-42A

F. F. Fondeur, 773-A

P. R. Jackson, 703-46A 